\title{
Seasonal dynamics in the trophic status of water, floral and faunal density along some selected coastal areas of the Red Sea, Tabuk, Saudi Arabia
}

\author{
Abid Ali Ansari - Sulaiman Al Ghanim • Subrata Trivedi • \\ Hasibur Rehman • Zahid Khorshid Abbas • Shalini Saggu
}

Received: 21 April 2015/Accepted: 20 October 2015/Published online: 17 November 2015

(C) The Author(s) 2015. This article is published with open access at Springerlink.com

\begin{abstract}
Eutrophication is posing a threat to the coastal marine ecosystems. The consequence of anthropogenic induced eutrophication of waters has resulted in severe deterioration of surface waters. In this research a preliminary data was collected on eutrophication by environmental monitoring on some selected coastal areas of the Red Sea near Tabuk, Saudi Arabia. Sampling sites were selected from Haql, Sharmaa and Duba (five for each station) and water samples collected in four different seasons (Oct 2013, Jan 2014, April 2014 and July 2014) to study seasonal dynamics of water quality parameters (especially in reference to the trophic status of water). Only one coastal site from each station was found with some eutrophic characteristics. Water samples collected from these eutrophic sites were more alkaline, turbid, with higher nutrient and low dissolved oxygen contents as compared to other sampling sites. Dynamics in relative densities of coastal flora and fauna were also found to be related with coastal water quality. Human settlements, fish markets, boating clubs and tourisms near these coastal areas of the Red Sea were observed as the primary causes of nutrient loading; run-offs during rains carrying nutrients also aggravate the problem. The results of this study may help in estimating the intensity of the problem and as a forecast for time frame to take an action for the conservation of affected coastal marine ecosystems and restoration of degraded coastal areas of the Red Sea.
\end{abstract}

Keywords Eutrophication $\cdot$ Coastal ecosystems $\cdot$ Red Sea $\cdot$ Bio-indicators

\section{Introduction}

Coastal eutrophication is one of the major threats to the marine ecosystems. The European Union (EU) Water Framework Directive (WFD) is given to prevent the deterioration, protect aquatic systems and to promote the sustainable use of water (Andersen et al. 2006). Hypoxia is one of the common effects of eutrophication in coastal marine ecosystems and is becoming an increasingly prevalent problem worldwide. The causes of hypoxia are associated with excess nutrient inputs from both point and non-point sources. Changes in climate, particularly temperature, may also affect the susceptibility of coastal marine ecosystems to hypoxia (Feuchtmayr et al. 2009). Hypoxia is a particularly severe disturbance because it causes death of biota and catastrophic changes in the ecosystem (Conley et al. 2009). The discovery of trophic development of waters and their terminology dates back to the early 20th century. The availability of water for human consumption will be one of the great issues of 21st century. It is predicted that eutrophication is increase as threats to water resources and ecosystems (Johanson et al. 2001; Liu et al. 2011; Ansari et al. 2014; Naeem et al. 2014).

A. A. Ansari $(\bowtie) \cdot$ S. A. Ghanim · S. Trivedi $\cdot$ H. Rehman $\cdot$ Z. K. Abbas · S. Saggu Department of Biology, Faculty of Science, University of Tabuk, Tabuk, Saudi Arabia e-mail: aansari@ut.edu.sa; aaansari40@gmail.com 
The consequences of anthropogenic induced eutrophication of waters however, were not anticipated until they became evident in the 1940s and 1950s. Severe deterioration of waters at that time raised remarkable public concern and triggered expanding scientific interest (Vollenweider 1970, Officer and Ryther 1980, Vollenweider and Kerekes 1980, Nixon 1995, Dokulil and Teubner 2011, Jeppesen et al. 2005). The biologists are studying it extensively in order to prevent eutrophication of aquatic bodies around the world (Yang et al. 2008). Eutrophication of coastal waters is a serious environmental problem with high costs for society globally. This is a development which demands immediate environmental action along many coastal sites (Lindahl and Kollberg 2009; Smith 2007). The consequence of anthropogenic induced eutrophication of waters has resulted in the contamination of surface water and related management issues which in turn has raised the brows of environmentalist across the world (Ansari et al. 2011a; Ansari and Khan 2011; Ansari and Gill 2014; Ansari and Khan 2014).The work on eutrophication was started by Vollenweider in 1968 and Rohlich in 1969. It is now evident that the nutrients are primarily responsible for limiting productivity in lakes, rivers and coastal areas (Likens 1972). Eutrophic ecosystems depend on many factors, including retention time, temperature, nutrients loading, hydraulic regimes, plant harvesting, and light intensity. The species compositions of phytoplankton are regulated by $\mathrm{pH}$, light, temperature, turbulence, salinity and nutrients contents of waters (El-Shafai et al. 2007, Ansari and Khan 2009b; Lu et al. 2010; Devlin and Witham 1986).Initially, $P$ and $C$ have drawn the attention of limnologists and ecologists as primary causes of eutrophication. However, now it is proved that $\mathrm{N}$ contributes in increasing eutrophication especially in estuaries where it is a limiting factor under normal conditions. Therefore, it is evident that $\mathrm{N}$ is a primary cause of eutrophication in many coastal ecosystems (Paerl et al. 2003). Phosphorus has been considered the principal limiting nutrient for primary production of phytoplankton in aquatic bodies (Philips 2002; Sharpley et al. 2003). Various studies showed that the anthropogenic nutrients input are directly related with intensity of coastal eutrophication and degradation of coastal areas (Polomski et al. 2009). Nonpoint sources of nutrients are more responsible than the point sources for eutrophication in many regions (Carpenter 2005). Eutrophication generate significant alterations in structure and functioning of a wetland ecosystem (Davis et al. 2003) and alter the physicochemical and biological characteristics of soil and water (Corstanje and Reddy 2006).

A regular environmental monitoring and assessment of eutrophication will provide a research data on level of degradation of marine ecosystems in coastal areas of the red sea. The work will be an ecological vision on this global problem of coastal eutrophication and its causes, consequences and controls, in special reference to coastal areas of Red Sea in the boundary of Kingdom of Saudi Arabia.

\section{Materials and methods}

Three coastal stations of the Red Sea viz. Haql (29 $\left.19^{\prime} 9.9^{\prime \prime} \mathrm{N} 34^{\circ} 56^{\prime} 18.9^{\prime \prime} \mathrm{E}\right)$, Sharmaa $\left(28^{\circ} 1^{\prime} 27.9^{\prime \prime} \mathrm{N} 35^{\circ}\right.$ $\left.16^{\prime} 9.9^{\prime \prime} \mathrm{E}\right)$ and Duba $\left(27^{\circ} 20^{\prime} 57.3^{\prime \prime} \mathrm{N} 35^{\circ} 41^{\prime} 46.2^{\prime \prime} \mathrm{E}\right)$ were selected for environmental monitoring and assessment of coastal eutrophication (Fig. 1). After every 500 meters five sampling sites from each station (Haql, Sharmaa and Duba) were selected starting from the residential area of the city near to the sea coast. Water samples were collected in four different seasons (Oct 2013, Jan 2014, April 2014 and July 2014) to study the seasonal variations in water quality parameters. Physico-chemical parameters ( $\mathrm{pH}$, Turbidity, DO, Magnesium, Calcium, $\mathrm{SiO}_{3}$, Phosphate and Nitrate) of collected waters samples were measured following APHA (2005). Data was analyzed statistically for the significance of research following Gomez and Gomez (1984) and computer software (SPSS for statistical analysis). Qualitative survey for the density of flora and fauna along the selected coastal areas of the Red Sea was also carried out in four different seasons of Tabuk. To determine the distribution of some plant and animal species along the coastal areas studied in this research, density was calculated. Five different sites were considered as replicates for each station.

Density in terms of occurrence and water surface occupied was expressed in four qualitative density classes. Negative (-) used to indicate non-occurrence and occurrence of the species. Single + indicates low density with sporadic occurrence, two ++ signs indicate for a medium density, three +++ shows high density of species with the dominance by a single species at particular coastal area of the Red Sea. 


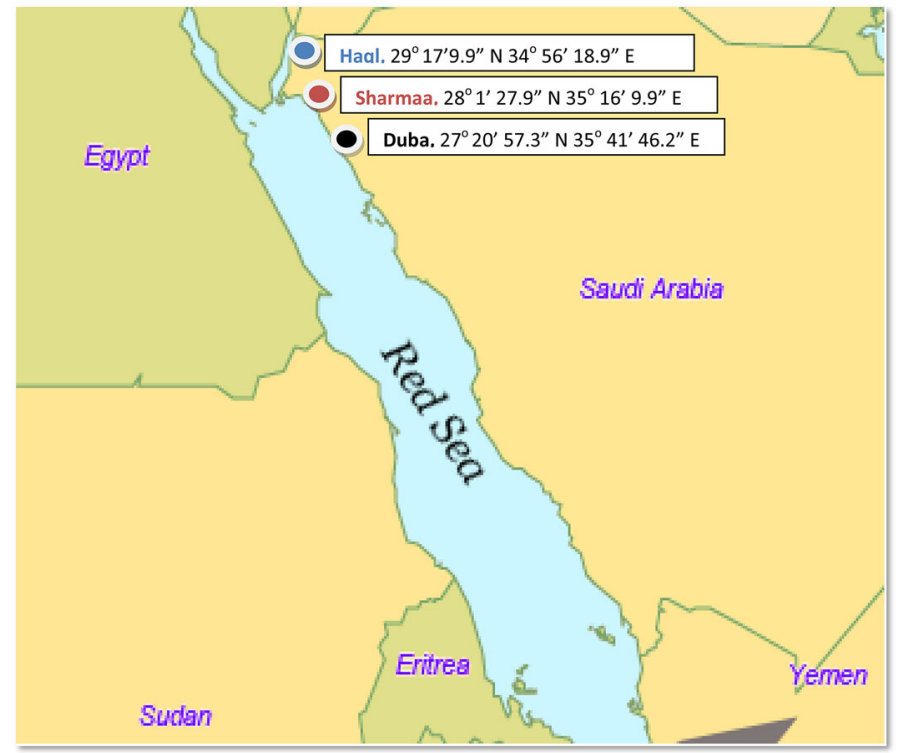

Fig. 1 Coastal stations of the Red Sea selected for environmental monitoring and assessment of coastal eutrophication

\section{Results}

Table 1 showed physico-chemical characteristics of water samples collected from five different sites along Red Sea coast at Haql, Tabuk, Saudi Arabia in October 2013 and January, April, July 2014. All the water samples were found with alkaline $\mathrm{pH}$, but maximum 8.5 was recorded at site S1 in the month of July 2014. Water temperature was at its peak $\left(22^{\circ} \mathrm{C}\right)$ at site S4 in the month of July 2014 . Water of S1 site was found more turbid than the samples from other coastal sites at Haql. Dissolved oxygen contents in water samples were significantly low at site S1 whereas optimum at rest of the sampling sites. Highest amount of oxygen in water was found at S5 in the month of April 2014. Magnesium, Calcium and Silica contents were significantly high in water samples collected from site S1. The nutrients contents viz. phosphates and nitrates in water samples were recorded significantly high at site S1. The statistical analysis of water quality parameters revealed that the symptoms of coastal eutrophication were more prominent in waters at site S1 only, whereas the water samples showed improvement in quality with the distance from site S1 (Table 1).

Table 2 showed physico-chemical characteristics of water samples collected from five different sites along Red Sea coast at Sharmaa, Tabuk, Saudi Arabia in October 2013 and January, April, July 2014. Most alkaline $\mathrm{pH} 8.8$ was recorded at site $\mathrm{S} 1$ in the month of October-2013. Water temperature was of its maximum $\left(20^{\circ} \mathrm{C}\right)$ at site S2 and S3 in the month of July 2014. The water temperature was as low as $7{ }^{\circ} \mathrm{C}$ in January-2014 at site S5. Water at S1 site was found more turbid than the samples from other coastal sites at Sharmaa. Dissolved oxygen contents in water samples were significantly low at site S1 whereas higher oxygen level in water observed at rest of the sampling sites. Magnesium, calcium and silica nitrates and phosphates contents in water were significantly higher at site $\mathrm{S} 1$ as compared to the other sampling site showing a decreasing trend with the distance from site S1 (Table 2).

Table 3 showed physico-chemical characteristics of water samples collected from five different sites along Red Sea coast at Duba, Tabuk, Saudi Arabia in October 2013 and January, April, July 2014. The water was most alkaline with a pH 8.7 at site S1 recorded in the month of January-2013. Highest water temperature of $21{ }^{\circ} \mathrm{C}$ was recorded at sites S3 and S4 in the month of July 2014. The water temperature goes $8{ }^{\circ} \mathrm{C}$ in January2014 at site S2. Water turbidity was high at site S1 as compared to the coastal sites at Duba. There was low content of dissolved oxygen in water samples from site S1 whereas significantly higher amount of oxygen was available in the water at rest of the sampling sites. Magnesium, calcium and silica nitrates and phosphates contents in water were significantly higher at site S1 in the month of January 2014, as compared to the other sampling site showing a decreasing trend with the distance from site S1 (Table 3). 


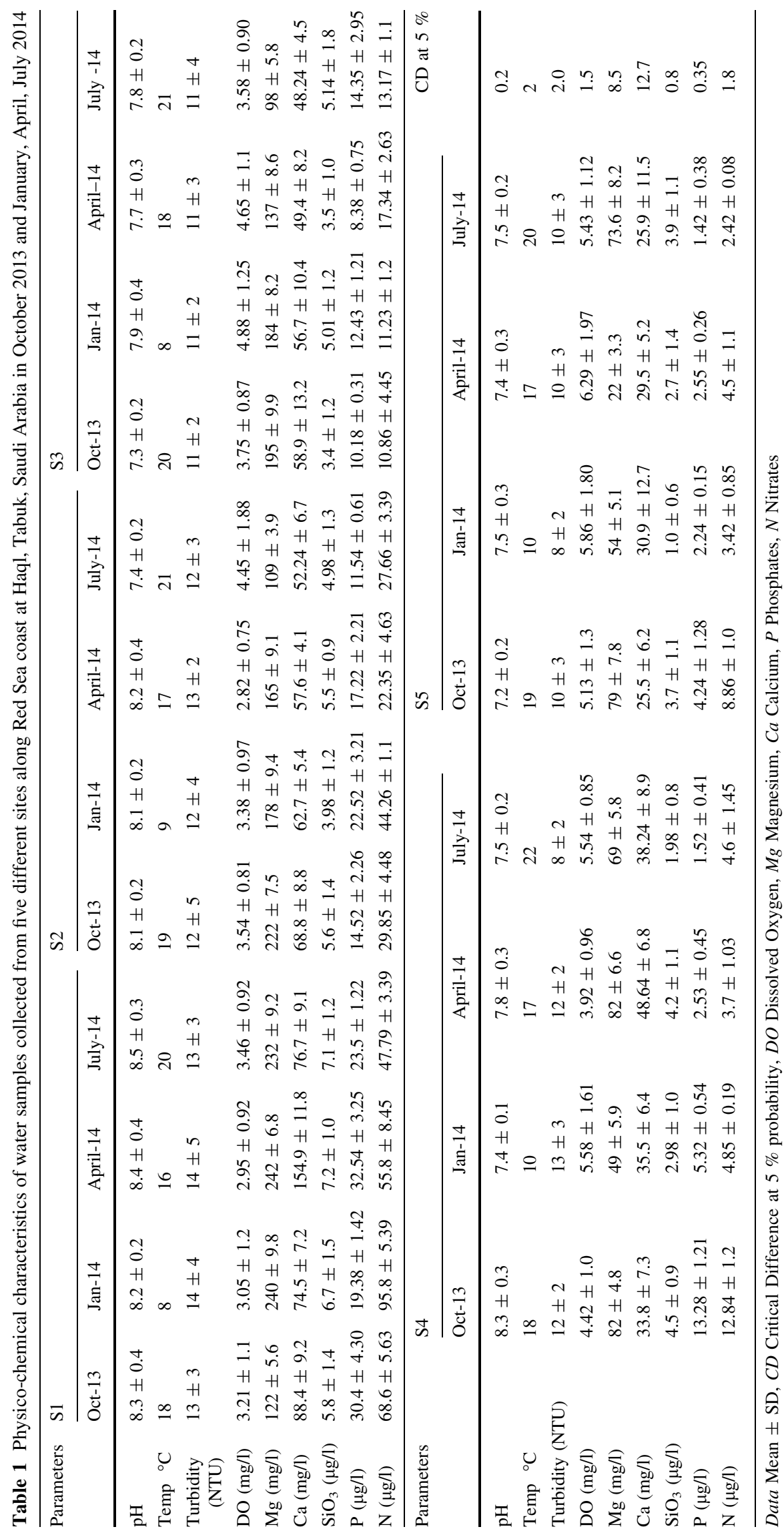




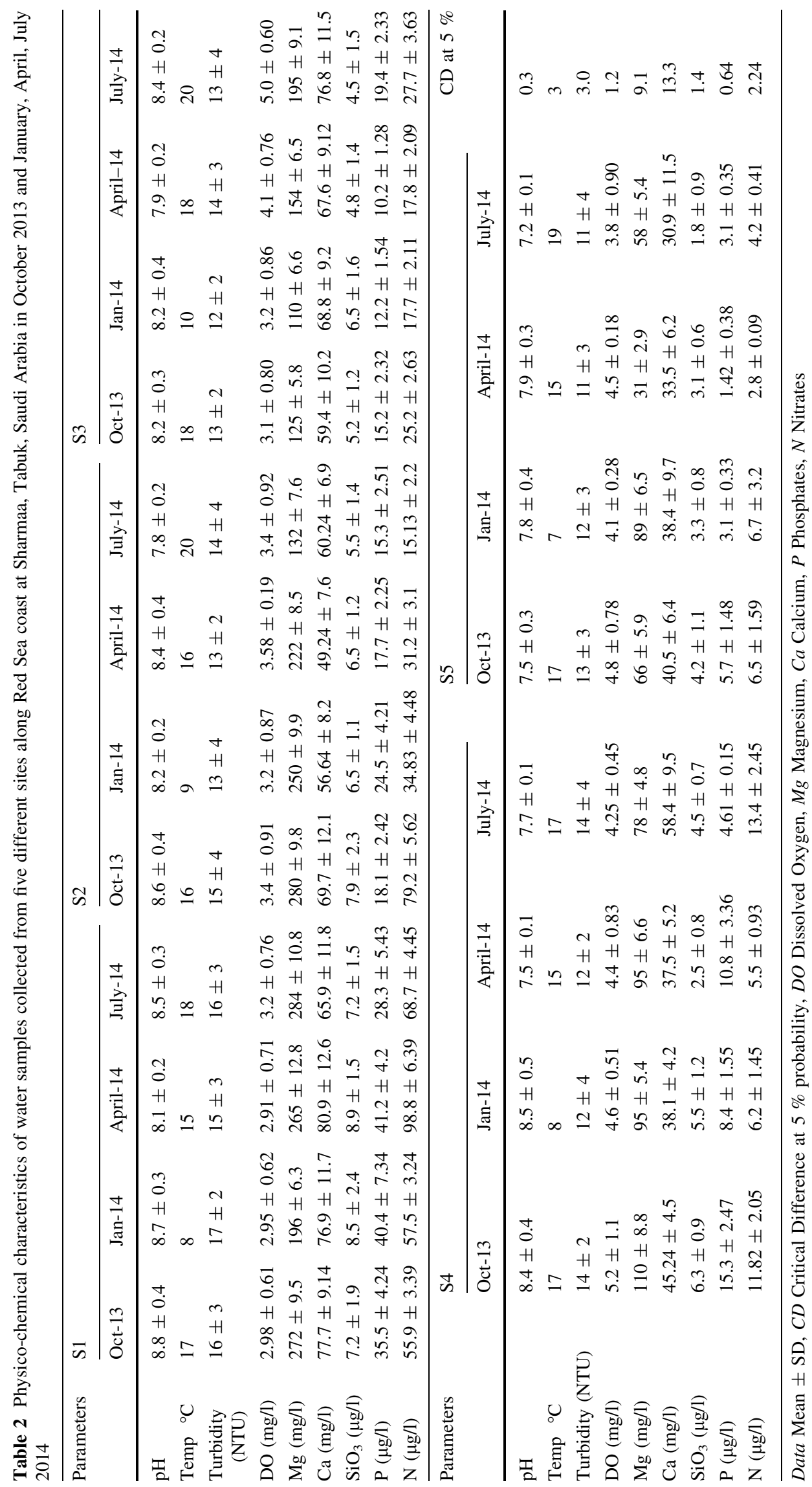




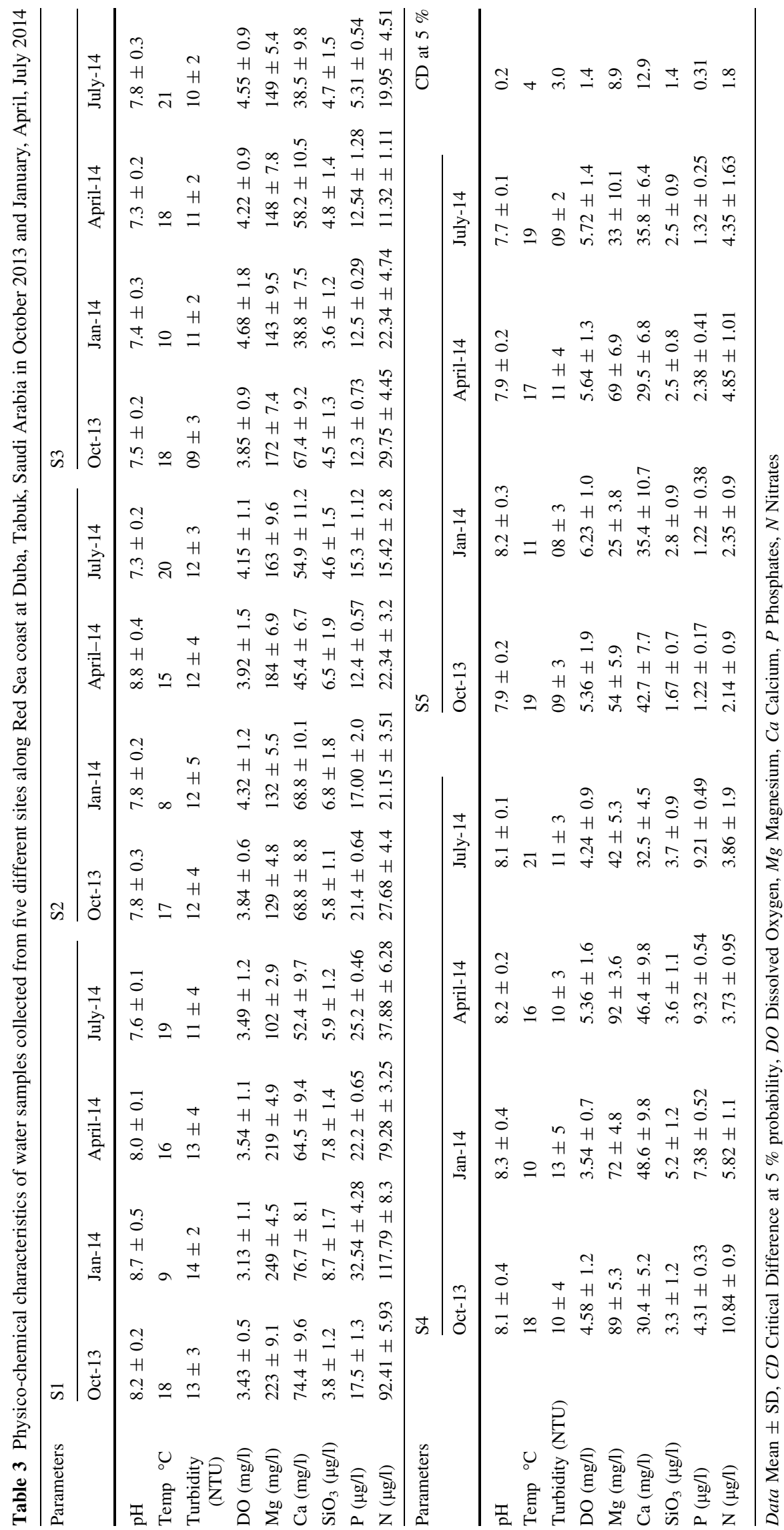




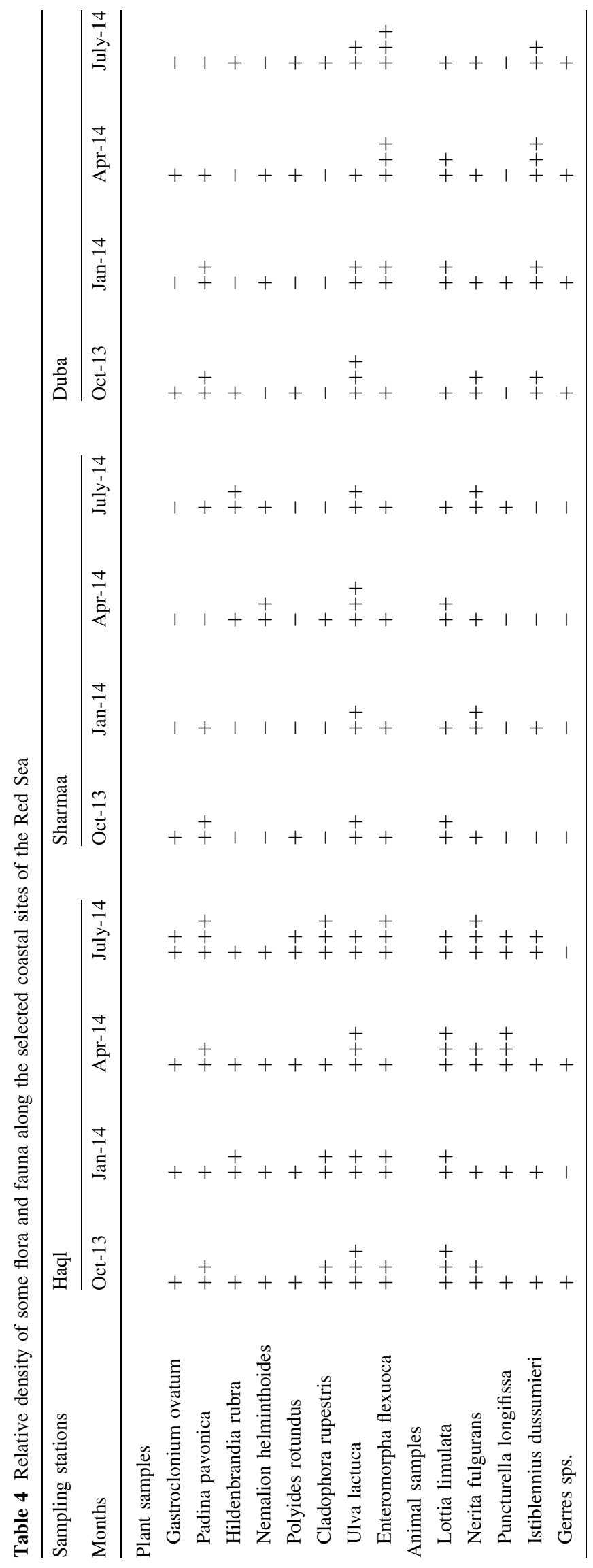


Table 4 showed the density of some flora and fauna along the selected coastal sites of the Red Sea. Among the diffrent plant species sudied along the selected coastal sites Ulva lactuca, Padina pavonica and Enteromorpha flexuоca showed higher densitities in most of the seasons at Haql station as compared to the other two stations at Sharmaa and Duba. Ulva lactuca showed its highest density at five selected sites of Haql station in October-2013 and April-2014. The densities of Lottia limulata and Boleophthalmus sps. were higher among the different animal spcies studied at coastal sites. Lottia showed its maximum density at Haql station in the month of October-2013, whereas Boleophthalmus at Duba station in April 2014 (Table 4).

\section{Discussion}

Many coastal waters of developed nations have experienced widespread and rapid eutrophication (the increase in supply of organic matter) during the last half of the 20th century. This has resulted in increased phytoplankton production, decreased water clarity, often-severe depletion of dissolved oxygen in bottom waters, loss of seagrasses and, in some cases, declines or changes in the quality of fisheries production (Andersen and Conley 2009; Sayyed 2008; Boesch and Brinsfield 2000). Recent national assessments documented that the nitrogen-driven coastal eutrophication is widespread and increasing in the United States. An aquatic system takes thousands of years to become eutrophic which is a natural process. However, a high rate of input of nutrients due to anthropogenic activities significantly enhance the condition in a very short period of time (Ansari and Khan 2002, 2006a, 2007). This is called cultural eutrophication. High chemical or physical stress also enhance the struggle for survival in eutrophic systems. As a result the diversity of organisms declines in eutrophic than in oligotrophic systems (Ansari 2005; Ansari and Khan 2006b, 2009a).

Continuous evaporation from the surface of Red Sea results into an increase in concentration of magnesium, calcium, silica, nitrates and phosphates and Khomayis (2002). Inorganic nitrogen in the form of nitrates and nitrites can be used as pollution indicator to correlate with phytoplankton composition. Inorganic nitrogen in an aquatic ecosystem stimulates the development, maintenance and proliferation of primary producers and results into eutrophication (Camargo and Alonso 2006, Fang et al. 2007)

This significant coastal pollution problem includes impacts including increased areas and severity of hypoxic and anoxic waters; alteration of food webs; degradation and loss of sea grass beds, kelp beds and coral reefs; loss of biodiversity; and increased incidences and duration of harmful algal blooms (Scavia and Bricker 2006). Increase in phytoplankton species, water temperature and frequent decomposition of dead planktons and other organic matter results in depletion of oxygen level (Calliaria et al. 2005). Light reduction in the water column and enhanced organic matter (OM) load into the sediments are two main consequences of eutrophication in marine coastal areas (Olive et al. 2009). In eutrophicated coastal waters seagrass decline was found associated with light intensity (Burkholder et al. 2007). Various treatments of light showed a significant effect on photosynthesis and acclimation in aquatic macrophytes (Jensen et al. 2006; Karlsson et al. 2009).

Temperature is one of important environmental factor for directly related with the functioning of an aquatic ecosystem (Ansari and Khan 2008, 2009b; Lau and Lane 2002; Shen 2002). Temperature is recognized as an important environmental factor in aquatic ecosystems as it regulates all the biological activities like metabolism, growth, development and reproduction. Seasonal variations in temperature strongly influence these biological activities. Long-term, changes in temperature of the surrounding environment directly affect the evolution, physiology and behavior of aquatic organisms (Begon et al. 1990, Regier et al. 1990).

In addition to more favorable temperatures during a particular season, there is some phonological specificity in developing plant and animal biomass (Picard et al. 2005). The temperature values recorded during spring appeared to be suitable for seaweeds growth. These data are in accordance of those of Kebede and Ahlgren (1996) reported $30^{\circ} \mathrm{C}$ as the optimum temperature growth and development of aquatic plants. pH controls absortion of nutrients and bichemical reactions taking place in living organisms. It is observed that more alkaline pH enhances the growth of phytoplankton (Ansari and Khan 2008, 2009b; Ansari et al. 2011b, 2011c).

Density represents the numerical strength of a species in the community. The number of individuals of the species in a unit area is its density. Density gives an idea of degree of competition (Sharma 2012). The high nutrient concentrations enhance the excessive growth of phytoplankton and macrophytes in aquatic ecosystem (Rovira and Pardo 2006, Ansari and Khan 2013). Eutrophication causes undesirable changes in species 
composition of an aquatic ecosystem (Romermann et al. 2008) and has been identified as the major threat to the survival of aquatic ecosystems and biodiversity (Murphy et al. 2003, Murphy 2002). Abdul-Aziz et al. (2003) reported blooming of phytoplankton in May and August influenced by temperature and nutrients in coastal waters of Arabian Gulf, Saudi Arabia. Species composition of the benthic phytoplankton in marine fouling area of Sharm Obhour (North Obhour), Red Sea was reported by Al-Harbi and Khomayis (2005). Khomayis (2002) studied the annual cycle of nutrient and chlorophyll-a in the coastal water of Jeddah, Red Sea and revealed the role of inorganic nutrients as limiting factors for the growth of phytoplankton.

Most of the countries around the globe have now realized the serious threat posed by eutrophication. The water bodies of countries like India, China, Bangladesh, Pakistan, Indonesia, Switzerland, Poland, Austria, Denmark, Croatia, Ireland, France, Greece, Estonia, Russia, Italy, Turkey, Japan great lakes states of the USA and Canada are under the direct threat of eutrophication (Ansari 2005). In the mid-20th century, eutrophication had been recognized as one of the causative factors of pollution in European and North American lakes and reservoirs. Since then, it has become more widespread and surveys showed that $54 \%$ of lakes in Asia, $53 \%$ in Europe, $48 \%$ in North America, $41 \%$ in South America and $28 \%$ in Africa are in eutrophic state (Colin et al. 2007). In Spain $80 \%$ of the lakes, $70 \%$ of the reservoirs and $60 \%$ river sites were eutrophic in the 1990s with hypertrophy increasing downstream (Alvarez-Cobelas et al. 2001; Khan and Ansari 2005; Khan et al. 2014). Three large coastal marine ecosystems (Chesapeake Bay, Northern Gulf of Mexico, and Danish Straits) showed repeated hypoxic events have led to an increase in susceptibility of further hypoxia and accelerated eutrophication (Conley et al. 2009). Large-scale changes resulting from coastal eutrophication have been documented for continental shelf waters in the Gulf of Mexico, Mediterranean, Black and North Seas, relatively confined seas such as the Baltic and Seto Inland Sea, large bays such as the Chesapeake Bay and Long Island Sound and numerous smaller estuaries and lagoons (Boesch and Brinsfield 2000).

The Red Sea is a narrow inland sea separating the Arabian Peninsula, western Asia, from northeastern Africa. It extends northwest from the strait of Bab el Mandeb to Suez, Egypt, for a distance of $1900 \mathrm{~km}$ (1200 mile). The northern extremity is divided by the Sinai Peninsula into the gulfs of Suez and Aqaba. The Suez Canal connects the Red Sea with the Mediterranean Sea and Bab El-Mandeb connects it with the Gulf of Aden, an arm of the Arabian Sea. The seasonal variations of the algal flora in the different water sources in Saudi Arabia in the Red Sea had been studied by only few workers (Touliabah et al. 2010). Kingdom of Saudi Arabia is sharing its boundary with seven countries and three water bodies. In the west Gulf of Aqaba and Red Sea form a coastal border of almost 1800 kilometres, which have a huge human settlement in terms of many towns and cities (viz. Al Lith, Al Qunfudhah, Al Wajh, Duba, Haql, Jeddah, Jazan, Rabigh, Thuwal, Yanbu). This large human population settled on the coasts significantly contributing nutrients to the coastal areas in the form of different wastes and causing coastal eutrophication. A survey on scientific literature shows a very little work has been done on the eutrophication of coastal areas in the boundary of Saudi Arabia. So, we have selected the present topic and taken a task for the preliminary research on the coastal eutrophication and its causes, consequences and controls. One time study cannot provide a forecast to imply effective control measures, much more data from the monitoring of coastal marine ecosystems for a longer duration is required to reach any conclusion. However, the results of this research may give a initial sign of the problem that can help in preventing a huge capital loss in order to control coastal eutrophication as compare to the condition when the problem is completely established. The study may be helpful in planning the research projects to combat the coastal eutrophication to restore and conserve the marine ecosystems and degraded coastal areasof the Red Sea in Saudi Arabia.

The consequences of coastal eutrophication caused by excessive anthropogenic inputs of nutrients are: Increase in biomass of phytoplankton, zooplanktons and macrophytes, domination of algal bloom forming species which is toxic to consumers of eutrophic ecosystem, increase in biomass of consumer species due to increase of biomass of benthic and epiphytic algae, anoxic conditions in the aquatic ecosystem results in frequent fish kills, decline in species diversity of aquatic ecosystem, decrease in harvestable fish biomass, decrease in water transparency. Problems related to the quality of water and its aesthetic value. In addition to increasing scientific knowledge, answers to these questions related to eutrophication can influence strategies for ecosystem restoration or rehabilitation (Hecky 2009, Smits 2005).

Acknowledgments The authors would like to acknowledge financial support for this work, from the Deanship of Scientific Research (DSR), University of Tabuk, Tabuk, Saudi Arabia, under the No. S-0021-1436. 
Open Access This article is distributed under the terms of the Creative Commons Attribution 4.0 International License (http:// creativecommons.org/licenses/by/4.0/), which permits unrestricted use, distribution, and reproduction in any medium, provided you give appropriate credit to the original author(s) and the source, provide a link to the Creative Commons license, and indicate if changes were made.

\section{References}

Abdul-Aziz PK, Al-Tisan IA, Daili MA, Green TN, Dalvi AGI, Javeed MA (2003) Chlorophyll and plankton of the RSA coastal waters of Saudi Arabia bordering a desalination plant. Desalination 154:291-302

Al-Harbi SM, Khomayis HS (2005) Seasonal variations of chlorophyll a and micro-nutrientsin Obhur Creek, Red Sea. J King Abdul-Aziz Univ Mar Sci 16:91-104

Alvarez-Cobelas M, Cirujano S, Sanchez-Carrillo S (2001) Hydrological and botanical man-made changes in the Spanish wetland of Las Tablas de Daimiel. Biol Conserv 97:89-98

Andersen JH, Conley DJ (2009) Eutrophication in coastal ecosystems, towards better understanding and management strategies. The Springer, Netherlands 264 pp

Andersen JH, Schluter L, Rtebjerg G (2006) Coastal eutrophication: recent developments in definitions and implications for monitoring strategies. J Plankton Res 28(7):621-628

Ansari AA (2005) Studies on the role of selected household detergents in the eutrophication of freshwater ecosystem. PhD thesis, Aligarh Muslim University, Aligarh

Ansari AA, Gill SS (2014) Eutrophication: causes, consequences and control. Springer, The Netherlands, p 264

Ansari AA, Khan FA (2002) Nutritional status and quality of water in a waste water pond of Aligarh showing blooms of Spirodela polyrrhiza L. (Shleid). J Ecophysiol Occupl Health 2:185-189

Ansari AA, Khan FA (2006a) Studies on the role of some selected nutrient sources in the eutrophication of freshwater ecosystem. Nat Environ Poll Technol 5:47-52

Ansari AA, Khan FA (2006b) Growth responses of Spirodela polyrrhiza treated with a common detergent at varying temperature and $\mathrm{pH}$ conditions. Nat Environ Poll Technol 5:399-404

Ansari AA, Khan FA (2007) Eutrophication studies on some freshwater ponds of Aligarh. Ind J Appl Pure Biol 22:21-26

Ansari AA, Khan FA (2008) Remediation of eutrophied water using Lemna minor in controlled environment. Afr J Aqua Sci 33:275-278

Ansari AA, Khan FA (2009a) Eutrophication studies on Jeffery canal of Aligarh International Conference on Emerging Technologies in Environmental Science and Engineering. International Conference, Aligarh Muslim University, Aligarh, India 845-849

Ansari AA, Khan FA (2009b) Remediation of eutrophied water using Spirodela polyrrhiza (L.) Shleid in controlled environment. Pan-Am J Aqua Sci 4:52-54

Ansari AA, Khan FA (2011) Nutrients phytoremediation of eutrophic waters using Eichhornia crassipes in a controlled environment. Int J Environ Sci 2:241-246

Ansari AA, Khan FA (2013) Response of Eichhornia crassipes to eutrophic waters receiving nutrients from various sources. Int J Environ Sci 4(1):39-45

Ansari AA, Khan FA (2014) Household detergents causing eutrophication in freshwater ecosystems. In: Ansari AA, Gill SS (eds) Eutrophication: causes, consequences and control, vol 2. Springer, The Netherlands, pp 139-164

Ansari AA, Gill SS, Khan FA (2011a) Eutrophication: Threat to aquatic ecosystems. In: Ansari AA, Gill SS, Lanza GR, Rast W (eds) Eutrophication: Causes, Consequences and Control. Springer, The Netherlands, pp 143-170

Ansari AA, Gill SS, Lanza GR, Rast W (2011b) Eutrophication: Causes, Consequences and Control. Springer, The Netherlands 394 pp

Ansari AA, Khan FA, Gill SS (2011c) Aquatic plant diversity in eutrophic ecosystems. In: Ansari AA, Gill SS, Lanza GR, Rast W (eds) Eutrophication: Causes, Consequences and Control. Springer, The Netherlands, pp 247-263

Ansari AA, Gill SS, Khan FA, Naeem M (2014) Phytoremediation systems for the recovery of nutrients from eutrophic waters. In: Ansari AA, Gill SS (eds) Eutrophication: Causes, Consequences and Control, vol 2. Springer, The Netherlands, pp 239-248

APHA (2005) Standard methods for the examination of water and wastewater, 21st edn. APHA, AWWA and WEF, New York, p 1368

Begon M, Harper JL, Townsend CR (1990) Ecology: individuals, populations, and communities, 2nd edn. Blackwell Scientific Publications, Oxford

Boesch D, Brinsfield R (2000) Coastal Eutrophication and Agriculture: Contributions and Solutions. Biological Resource Management Connecting Science and Policy, 93-115

Burkholder JM, Tomasko DA, Touchette BW (2007) Sea grasses and Eutrophication. J Exp Mar Biol Ecol 350:46-72

Calliaria D, Gomez M, Gomez N (2005) Biomass and composition of phytoplankton. Cont Shelf Res 25:197-210

Camargo JA, Alonso A (2006) Ecological and toxicological effects of inorganic nitrogen pollution in aquatic ecosystems: a global assessment. Environ Int 32(6):831-849

Carpenter SR (2005) Eutrophication of aquatic ecosystems: bistability and soil phosphorus. PNAS 102:10002-10005

Colin RB, Robert E, Wreede D (2007) Do changes in seaweed biodiversity influence associated invertebrate epifauna? J Exp Mar Biol Ecol 344:206-214

Conley DJ, Carstensen J, Vaquer-Sunyer R, Duarte CM (2009) Ecosystem thresholds with hypoxia. Hydrobiologia 629(1):21-29

Corstanje R, Reddy KR (2006) Microbial indicators of nutrient enrichment: a mesocosm study. Soil Sci Soc Am J 70:1652-1661 
Davis SE, Corronado-Molina C, Childers DL, Day JW (2003) Temporally dependent C, N, and P dynamics associated with the decay of Rhizophora mangle L., leaf litter in oligotrophic mangrove wetlands of the Southern Everglades. Aquat Bot 75:199-215

Devlin RM, Witham FH (1986) Plant physiology, 4th edn. CBS Publishers, New Delhi

Dokulil MT, Teubner K (2011) Eutrophication and climate change: Present situation and future scenarios. In: Ansari AA, Gill SS, Lanza GR, Rast W (eds) Eutrophication: causes consequences and control. Springer, New York, pp 1-16

El-Shafai SA, El-Gohary FA, Nasr FA, Van der Steen NP, Gijzen HJ (2007) Nutrient recovery from domestic wastewater using a UASB-duckweed ponds system. Biores Technol 98:798-807

Fang YY, Babourina O, Rengel Z, Yang XE, Pu PM (2007) Ammonium and nitrate uptake by the floating plant Landoltia punctata. Ann Bot 99:365-370

Feuchtmayr H, Moran R, Hatton K (2009) Global warming and eutrophication: effects on water chemistry and autotrophic communities in experimental hypertrophic shallow lake mesocosms. J Appl Ecol 46:713-723

Gomez KA, Gomez AA (1984) Statistical procedures for agricultural research, 2nd edn. Wiley and Sons, New York, pp 680

Hecky RE (2009) Eutrophication: more nitrogen data needed. Science 324:721-772

Jensen JP, Pedersen AR, Jeppesen E, Søndergaard M (2006) An empirical model describing the seasonal dynamics of phosphorus in 16 shallow eutrophic lakes after external loading reduction. Limnol Oceanogr 51:791-800

Jeppesen E, Søndergaard M, Jensen JP, Lauridsen TL (2005) Shallow Lakes: Effects of Nutrient Loading and How to Remedy Eutrophication. I: Encyclopedia of Life Support Systems (EOLSS): Developed under the Auspices of the UNESCO. Oxford, UK

Johanson N, Revenga C, Echeverria J (2001) Managing water for people and nature. Science 292:1071-1072

Karlsson J, Bystrom P, Ask J (2009) Light limitation of nutrient-poor lake ecosystems. Nature 460:506-509

Kebede E, Ahlgren G (1996) Optimum growth conditions and light utilization efficiency of Spirulina platensis (=Arthrospira fusiformis) (Cyanophyta) from Lake Chitu. Ethiopia Hydrobiol 332(2):99-102

Khan FA, Ansari AA (2005) Eutrophication: an ecological vision. Bot Rev 71:449-482

Khan FA, Naushin F, Rehman F, Masoodi A, Irfan M, Hashmi F, Ansari AA (2014) Eutrophication: Global scenario and local threat to dynamics of aquatic ecosystems. In: Ansari AA, Gill SS (eds) Eutrophication: causes, consequences and control, vol 2. Springer, The Netherlands, pp 17-28

Khomayis HS (2002) The annual cycle of nutrient salts and chlorophyll a in the coastal waters of Jeddah, Red Sea. J King AbdulAziz Univ Mar Sci 13:131-145

Lau SSS, Lane SN (2002) Biological and chemical factors influencing shallow lake eutrophication: a long-term study. Sci Tot Environ 3:167-181

Likens GE (1972) Nutrients and eutrophication: the limiting nutrient controversy. Limnol Oceanogr 1:321-328

Lindahl O, Kollberg S (2009) Can the EU agri-environmental aid program be extended into the coastal zone to combat eutrophication? Hydrobiologia 629(1):59-64

Liu Q, Hu C, Long W, Wang H, Zhou S (2011) International symposium on water resource and environmental protection (ISWREP), 3: 2239-2242

Lu Q, He ZL, Graetz DA, Stoffella PJ, Yang X (2010) Phytoremediation to remove nutrients and improve eutrophic stormwaters using water lettuce (Pistia stratiotes L.). Environ Sci Pollut Res 17:84-96

Murphy KJ (2002) Plant communities and plant diversity in softwater lakes of northern Europe. Aquat Bot 73:287-324

Murphy KJ, Dickinson G, Thomaz SM (2003) Aquatic plant communities and predictors of diversity in a subtrophical river flood plain: the upper Rio Parana Brazil. Aquat Bot 77:257-276

Naeem M, Idrees M, Khan MMA, Moinuddin Ansari AA (2014) Task of mineral nutrients in eutrophication. In: Ansari AA, Gill SS (eds) Eutrophication: causes, consequences and control, vol 2. Springer, The Netherlands, pp 223-238

Nixon SW (1995) Coastal marine eutrophication: a definition, social causes, and future concerns. Ophelia 41:199-219

Officer CB, Ryther JH (1980) The possible importance of slllconIn marine eutrophication. Mar Ecol Prog Ser 3:83-91

Olive I, Garcia-Sanchez MP, Brun FG, Vergara JJ (2009) Interactions of light and organic matter under contrasting resource simulated environments: the importance of clonal traits in the seagrass Zostera noltii. Hydrobiologia 629(1):199-208

Paerl HW, Valdes LM, Pinckney JL (2003) Phytoplankton photopigments as indicators of estuarine and coastal eutrophication. Bio Sci 53:953-964

Philips EJ (2002) Algae and eutrophication. In: Bitton G (ed) Encyclopedia of environmental microbiology. John Wiley and Sons, New York

Picard CR, Fraser LH, Steer D (2005) The interacting effects of temperature and plant community type on nutrient removal in wetland microcosms. Biores Technol 96:1039-1047

Polomski RF, Taylor MD, Bielenberg DG (2009) Nitrogen and phosphorus remediation by three floating aquatic macrophytes in greenhouse-based laboratory-scale subsurface constructed wetlands. Water Air Soil Pollut 197:223-232

Regier HA, Holmes JA, Pauly D (1990) Influence of Temperature Changes on Aquatic Ecosystems: an Interpretation of Empirical Data. Trans Am Fisher Soc 119(2):374-389

Rohlich GA (1969) Eutrophication: causes, consequences, correctives. National Academy of Sciences, Washington 307

Romermann C, Tackenberg O, Poschlod AJKP (2008) Eutrophication and fragmentation are related to species' rate of decline but not to species rarity: results from a functional approach. Biodivers Conserv 17:591-604

Rovira JL, Pardo P (2006) Nutrient pollution of waters: eutrophication trends in European marine and coastal environments. Contrib Sci 3:181-186

Sayyed MK (2008) Marine environment (In: Arab Environment: Future Challenges) (eds.) Tolba M.K. and Saab N.W. A report of Arab Forum for Environment and Development (AFED) 75-94

Scavia D, Bricker SB (2006) Coastal eutrophication assessment in the United States. Biogeochemistry 79:187-208

Sharma PD (2012) Ecology and Environment, 12th Edition. Rastogi Publications, India, pp 708 
Sharpley AN, Daniel T, Sims T, Lemunyon J, Stevens R, Parry R (2003) Agricultural Phosphorus and Eutrophication, 2nd ed, U.S. Department of Agriculture, Agricultural Research Service, ARS-149, pp 44

Shen DS (2002) Study on limiting factors of water eutrophication of the network of river in plain. J Zheji Univ Agric Life Sci 28:94-97

Smith VH (2007) Using primary productivity as an index of coastal eutrophication: the units of measurement matter. J Plankton Res 29:1-6

Smits EP (2005) Phytoremediation. Annual RevPlant Biol 56:15-39

Touliabah HE, Abu El-Kheir WS, Kuchari MG, Abdulwassi NIH (2010) Phytoplankton composition at Jeddah Coast-Red Sea, Saudi Arabia in relation to some ecological factors. J King Abdul-Aziz Univ Sci 22(1):115-131. doi:10.4197/Sci.22-1.9

Vollenweider RA (1968) The scientific basis of lake eutrophication, with particular reference to phosphorus andnitrogen as eutrophication factors. Technical report OECD, Paris, p 159

Vollenweider RA (1970) Models for calculating integral photosynthesis and some implications regarding structural properties of the community metabolism of aquatic systems. Prediction and measurements of photosynthetic productivity. Proc IBP/PP Meeting Trebon, Wageningen, pp 455-472

Vollenweider RA, Kerekes J (1980) The loading concept as basis for controlling eutrophication philosophy and preliminary results of the OECD programme on Eutrophication. Prog Water Tech 17:5-38

Yang X, Wu X, Hao H, He Z (2008) Mechanisms and assessment of water eutrophication. J Zhejiang Univ Sci B 9(3):197-209 